\title{
Effect of Incorporating Organic Materials into A Clay Soil of Lajas Valley on the Yields of Food Crops
}

\author{
J. A. Bonnet, M. A. Lugo-López, and M. Rico-Ballester ${ }^{\mathrm{I}}$
}

\section{INTRODUCTION}

The beneficial effects of organic-matter additions to some soils have been generally recognized. In an intensive program of research geared towards the better utilization of the heavy soils of Lajas Valley, in semiarid southwestern Puerto Rico, where an irrigation project is under way, the possibilities of using organic materials for improvement of the soil physical conditions could not be overlooked. For this purpose organic materials may be advantageously used instead of the rather expensive synthetic soil conditioners.

The soils of Lajas Valley are deep and have an almost uniformly high clay content throughout the profile, and a rather slow permeability at the subsoil. Many of the present practical drainage problems are complicated by salinity and alkalinity hazards $(1)^{2}$. Lugo-López, et al. (8) have reported that the application of synthetic soil conditioners to a clay soil in the Valley did not affect the yields of tomatoes, beans, and sweetpotatoes.

This paper reports on a field experiment designed to explore the possibility for soil improvement of organic byproducts of the sugar industry, such as filter-press cake and bagasse, together with a commercial source of an organic material.

\section{MATERIALS AND METHODS}

The experimental field was located on the Agricultural Experiment Substation farm near the town of Lajas in the semiarid southwestern region. The soil selected was a typical Santa Isabel clay, a compact soil of the terraces and alluvial fans (11). It is rich in feldspars of the oligoclase, albite, and labradorite types, and both kaolin and illite are the predominant clay minerals (4).

The experiment was laid out following a balanced incomplete-block design with seven treatments replicated six times in a 14-block arrangement. The plots were 4 feet $\times 6$ feet in size. The treatments included the

1 Head of the Department of Soils, Associate Soil Scientist, and Research Assistant in Agronomy, respectively, Agricultural Experiment Station, University of Puerto Rico, Río Piedras and Lajas, P. R. Appreciation is expressed to R. Vázquez, who helped in laying out the experiment in the field.

2 Italic numbers in parentheses refer to Literature Cited, pp. 177-8. 
following organic materials: Bagasse, filter-press cake, and a commercial organic product each at two levels, 20 and 40 tons of dry material to the acre. The organics were incorporated by hand-hoeing on June 2,1954 , into the topmost 6 inches of soil at the 20-ton level and to a 12-inch depth at the 40-ton level. Untreated control plots received the same hoeing treatment as the plots receiving organic materials at the rate of 20 tons per acre, i.e., they were worked with hoes down to a 6-inch depth to minimize as much as possible any differences other than those imposed by treatment.

Three crops were grown on the same plots in the following sequence: Corn, white beans, and sweetpotatoes. The plots were irrigated whenever needed as indicated by a 9-inch deep-mercury tensiometer.

Corn, Mayorbela variety, was planted on June 8, 1954 at a 11/2-foot distance between hills, three seeds to a hill. A 9-10-5 fertilizer was applied at planting time at the rate of 500 pounds to the acre, followed 21 days later by a side-dressing with ammonium sulfate. The plants were sprayed several times with a 4-percent solution of DDT and with Vapophos to keep pests under control. Corn ears were harvested on September 25 and October 4,1954 . The plots received a total of 31.5 inches of water, including 8 inches from irrigation.

White beans, Bonita selection, were planted on November 2, 1954 at a 4-inch distance between hills, three seeds to a hill, later thinned to two plants per hill. They received the same fertilizer as the previous corn crop, but at a rate of 800 pounds to the acre. Pests were kept under control by spraying thrice during the growing season with DDT at the same strength as was used with corn. The beans were harvested on January 17, 1955. The crop received a total of 6.5 inches of water including 2 inches from irrigation.

Sweetpotatoes, U.P.R., No. 3 variety, were planted on July 1, 1955. They were fertilized with an 8-8-13 fertilizer at the rate of 800 pounds to the acre. Several sprays with Aldrin, DDT, and BHC were required to keep pests under control. The crop was harvested on November 15-16. It received a total of 37.5 inches of water including 29.5 from rainfall fairly well distributed during the season.

\section{RESULTS AND DISCUSSION}

Data on the production of field corn, white beans, and sweetpotatoes as affected by the organic materials are presented in table 1. Highly significant differences were measured in the corn crop, the first in the sequence. The use of bagasse at rates of 20 and 40 tons to the acre and incorporated into the topmost 6 and 12 inches of soil, respectively, was detrimental to the growth and production of field corn. The germination of corn in the plots 
where bagasse was incorporated was very poor and extensive replanting was needed. In these plots the plants were weak and chlorotic and did not develop and grow as well as the plants from other treatments. Side-dressing with ammonium sulfate at an early date was ineffective. This was because of the competition for nitrogen of the soil heterotrophic micro-organisms with the plant while decomposing an organic material such as bagasse, that has a wide carbon-nitrogen ratio. Filter-press cake and the commercial organic product used had a narrower $\mathrm{C} / \mathrm{N}$ ratio, and consequently did not induce a competition between the micro-organisms and the plants.

TABLE 1.-Mean yields of corn, beans, and sweetpotatoes in Santa Isabel clay with 3 organic materials incorporated at 2 depths

\begin{tabular}{|c|c|c|c|c|c|c|}
\hline \multirow[b]{2}{*}{ Treatment No. } & \multicolumn{3}{|c|}{ Soil treatment } & \multicolumn{3}{|c|}{ Crop yiclds per acre } \\
\hline & Organic material & Rate & $\begin{array}{l}\text { Depth of } \\
\text { incorpor- } \\
\text { ation }\end{array}$ & Corn & Beans & $\begin{array}{l}\text { Sweet- } \\
\text { potatoes }\end{array}$ \\
\hline & & $\begin{array}{c}\text { Tons } \\
\text { per acre }\end{array}$ & Inches & Cwot. & Cwt. & Csot. \\
\hline 1 & Filter-press cake & 20 & 6 & 56.8 & 23.0 & 129.9 \\
\hline 2 & Bagasse & 20 & 6 & 18.2 & 22.4 & 81.7 \\
\hline 3 & $\begin{array}{l}\text { Commercial organic } \\
\text { product }\end{array}$ & 20 & 6 & 51.4 & 22.1 & 131.9 \\
\hline 4 & Filter-press cake & 40 & 12 & 62.9 & 23.3 & 117.1 \\
\hline 5 & Bagasse & 40 & 12 & 13.0 & 21.5 & 124.3 \\
\hline 6 & $\begin{array}{l}\text { Commerical organic } \\
\text { product }\end{array}$ & 40 & 12 & 49.3 & 23.0 & 128.9 \\
\hline 7 & Check & 0 & 6 & 47.5 & 21.8 & 107.3 \\
\hline \multirow{2}{*}{\multicolumn{4}{|c|}{$\begin{array}{l}\text { L.S.D. at the 5-percent level } \\
\text { L.S.D. at the 1-percent level }\end{array}$}} & 9.5 & 6.3 & 76.0 \\
\hline & & & & 12.8 & 8.4 & 102.4 \\
\hline
\end{tabular}

Filter-press cake at the 40 -ton rate significantly outyielded the bagasse at both levels, the commercial organic material at the higher level and the untreated plots.

The bean crop planted some 5 months after establishing the treatment differentials developed normally. No significant differences in yields of dry beans between treatments were measured. In general, the bean yields were rather good, over 20 hundredweights per acre. No significant differences attributable to treatment were measured in the sweetpotato crop, the third in the sequence, planted about 13 months after establishing the treatment differentials.

The effects of organic-matter additions to the soil on crop yields are dependent on several factors, such as nature of the soil, amount of organic 
matter added, and activity of the organic materials (5). Lugo-López, et al. $(7,9)$ have shown that additions of organic matter to normal latosols with open, porous structure are of rather doubtful value, while in heavytextured humid-region nonlatosols such additions may result in increased organic-matter levels and better crop yields. Bonnet and Lugo-López (2), after a period of 13 months, found no increase in soil organic matter as a result of plowing under $\mathbf{5}$ to $\mathbf{1 0}$ tons of velvetbean green manure followed by two corn crops. No residual effect on yields of corn were observed in this field. When 25 tons of the green manure were plowed under a slight increase in organic matter was evident. Increases in organic matter and in sugarcane yields were measured after 6 years of continuous additions of sugarcane trash to a clay soil in the Río Piedras area $(6,10)$.

The incorporation of velvetbean green manure in a latosol in the vicinity of Mayagüez did not produce an increase in organic matter, but caused significant yield increases of sweetpotatoes and corn (3). The response in yields may be attributable to a higher nitrogen supply from the activity of the legume. This nitrogen was used quickly by the growing crops. Such a rapid release of nitrogen with legume mulches under tropical conditions has been emphasized (12).

Organic-matter additions may play an important role in the reclamation, utilization, and conservation of many problem soils in the Lajas Valley. The establishment of a vegetation should receive also attention due to the role of roots in stabilizing soil structure, as a means of improving soil conditions for plant growth.

\section{SUMMARY}

Data have been presented here from a field experiment where bagasse, filter-press cake, and a commercial organic material were incorporated into a Santa Isabel clay soil under irrigation at the rates of 20 and 40 tons of dry material to the acre. The organic materials at the low level were hand-hoed into the topmost 6 inches of soil, while at the high level they were hoed to a 12-inch depth. Three crops: Corn, white beans, and sweetpotatoes, were grown consecutively in the sequence following the establishment of the treatment differentials. Bagasse, at both levels, depressed the yields of corn in a highly significant way. The use of filter-press cake at the rate of 40 tons to the acre outyielded bagasse at both rates, the commercial organic material at the high rate, and the check. No significant effects were measured on the bean and sweetpotato crops planted about 5 and 13 months, respectively, after establishing the treatment differentials. The growth of the latter was more uniform than that of corn.

The results are discussed briefly along with other results obtained under different conditions in Puerto Rico. 


\section{RESUMEN}

Se presentan aqui datos sobre un experimento de campo en donde se incorporaron materiales orgánicos a un suelo Santa Isabel arcilloso bajo riego en el Valle de Lajas. Los materiales usados fueron bagazo, cachaza y un producto orgánico comercial. En unos tratamientos estos materiales se incorporaron a las primeras 6 pulgadas de suelo, a razón de 20 toneladas por acre y en otros, hasta 12 pulgadas de profundidad, a razón de 40 toneladas por acre.

Se sembraron y cosecharon consecutivamente maí, habichuelas blancas y batatas mameyas en las parcelas después de la incorporación al suelo de los materiales orgánicos antes mencionados. La incorporación de bagazo al suelo, a ambos niveles, resultó en una reducción de los rendimientos de maíz. La cachaza, a razón de 40 toneladas por cuerda, resultó superior en su efecto al bagazo, a ambos niveles sobre la cosecha de maíz y también al orgánico comercial al nivel más alto y a la práctica corriente de no incorporar material orgánico al suelo. No se obtuvieron aumentos significativos en los rendimientos de las cosechas subsiguientes debido a los tratamientos. El crecimiento de estas fué más uniforme que el del maíz.

Los resultados obtenidos en este trabajo se discuten brevemente a la luz de la evidencia experimental previamente obtenida bajo otras condiciones en Puerto Rico.

\section{LITERATURE CITED}

1. Bonnet, J. A., and Brenes, E. J., Salinity status of Lajas Valley, J. Agr. Univ. P. R., 41(1) 25-34 1957.

2. Bonnet, J. A., and Lugo-López, M. A., Effect of different quantities of velvetbean green manure on corn yields in Puerto Rico, J. Agr. Univ. P. R. 37(1) 96$101,1953$.

3. Bonnet, J. A., Tirado-Sulsona, P., and Abruña, F., Effect of lime-phosphorus and green manure on sweetpotatoes and corn grown in acid soils. J. Agr. Univ. P. R. 31(4) 303-21, 1947.

4. Jeffries, C. D., Bonnet, J. A., and Abruna, F., The constituent minerals of some soils of Puerto Rico, J. Agr. Univ. P. R. 37(2) 114-39, 1953.

5. Joffe, J. S., Green manuring viewed by a pedologist, Advances in Agronomy VII, (Norman, A. G., ed.) Academic Press Inc., N. Y. pp. 141-87, 1955.

6. Landrau Jr., P., and Samuels, G., The handling of sugarcane trash: I, Yields and economic considerations, J. Agr. Univ.P. R. 36(3) 240-5, 1952.

7. Lugo-López, M. A., Bonnet, J. A., Hernández-Medina, E., Landrau Jr., P., and Samuels, G., Soil organic-matter levels and crop yields in Puerto Rico, Soil Sci. Soc. Amer. Proc. 18(4) 489-93, 1954.

8. Lugo-López, M. A., Bonnet, J. A., Rico-Ballester, M., and Acevedo, G., Lack of response of some food crops to the application of synthetic conditioners to a clay soil in Lajas Valley, J. Agr. Univ. P.R. 41(3) 167-72, 1957.

9. Lugo-López, M. A., Hernóndez-Medina, E., and Landrau Jr., P., Differential response of some tropical soils to additions of organic matter, J. Agr. Univ. P. R. 40(1) 70-7, 1956. 
10. Lugo-López, M. A., Landrau Jr., P., and Samuels, G., The handling of sugarcane trash: II, Effects of various practices upon soil properies, J. Agr. Univ. P. R. 36(3) 246-54, 1952.

11. Roberts, R. C., Soil survey of Puerto Rico, USDA in cooperation with Univ. P. R. Agr. Exp. Sta., Series 1936(8), 1942.

12. Vicente-Chandler, J., Mulches, An important item in tropical agriculture, $J$. Soil \& Water Conserv. 8(3) 136-40, 1953. 